ISSN 0258-7122

Bangladesh J. Agril. Res. 34(4) : 623-631, December 2009

\title{
EFFECT OF PACKAGING TECHNIQUES AND CHLORINATION ON THE QUALITY AND SHELF LIFE OF COUNTRY BEAN (Lablab niger)
}

\author{
MOHAMMAD MIZANUR RAHMAN ${ }^{1}$, MD. SHAHJAHAN ${ }^{2}$, MD. MIARUDDIN $^{3}$ \\ AND MD. GOLAM FERDOUS CHOWDHURY ${ }^{4}$
}

\begin{abstract}
The experiment was conducted to evaluate the effect of packaging materials on the quality and shelf life of country bean (Lablab niger) using passive modification of modified atmosphere packaging system. The modified atmosphere was created by making perforation in the packets made by polypropylene. Bean pre-treated with chlorine water and then packaging in selected polypropylene resulted substantial reduction in losses caused by weight loss and rotting/shriveling. These treatment combinations also considerably retained vitamin C, $\beta$-carotene, moisture content, etc. Under this condition, the retention of quality and shelf life of bean could be extended upto 8 days at ambient condition as compared to non-treated and without packaging.
\end{abstract}

Key Words : Packaging techniques, chlorination, shelf life, country bean.

\section{Introduction}

Country bean (Lablab niger) is one of the major fruit vegetables from the leguminasae family. In addition to the protein contributions of the legumes, these are also rich in other nutrients, such as starch, dietary fiber, protective phytochemicals, oil, vitamins and mineral elements (Saikia et al., 1999). The total vegetable production in Bangladesh is about 72.78 lakh metric tons from 6.04 lakh hectares of land in 2004-2005 (DAE, 2006). A large quantity of these vegetables is lost due to lack of proper postharvest handling, transportation, packaging and storage facilities. The postharvest losses of vegetables in the developing countries lie between $20 \%$ and $50 \%$ and between $5 \%$ and $25 \%$ in the developed countries (Amiruzzaman, 2000). Since beans are highly perishable as other vegetables, these are also subject to huge losses during the peak production season mainly through transportation, storage and marketing.

In the super market, the shelf life of leafy/fruit vegetables has been found to be very short. The suppliers generally use gunny bags, big cartoons or boxes for carrying vegetables. The market authority stored the collected vegetables in different chambers in their cold room. They maintain the temperature at around $20{ }^{\circ} \mathrm{C}$, but they do not maintain the humidity. As a result, the respiration rate is

\footnotetext{
${ }^{1 \& 4}$ Scientific Officer, Postharvest Technology Division, BARI, Joydebpur, Gazipur 1701, ${ }^{2}$ Principal Scientific Officer, Postharvest Technology Division, BARI, Joydebpur, Gazipur 1701, ${ }^{3}$ Senior Scientific Officer, Postharvest Technology Division, BARI, Joydebpur, Gazipur 1701, Bangladesh.
} 
high and the vegetables to deteriorate quickly. The storage of vegetables in small packet with or without some pretreatments and controlling its humidity may extend the shelf life of the vegetables. Pretreatments of vegetables with potassium permanganate or chlorine water before packaging exhibit better shelf life in room temperature (Giraldo et al., 1977). Again, the demand of the consumers is only one to two kilograms. However, there is no standard packet of such quantity. Standardization of packages will extend the shelf life of vegetables as well as reduce the postharvest losses.

\section{Materials and Method}

Fresh country beans (Lablab niger) were collected from the nearby producers. In the laboratory, the beans were sorted out to remove the anthracnose affected, over matured and damaged ones. The experiment was laid out in CRD factorial with 2 factors and three replications. The first factor was differently perforated packaging and the second factor was with chlorine (200ppm chlorox/halotab, 2 tablets per 1.5 litre water) water treatment. Each replication of the treatments consisted of $500 \mathrm{~g}$ vegetables. Polypropylene was used as packaging material and the packages were modified with different perforations $(0 \%, 0.5 \%, 1.0 \%$ and $1.5 \%$ perforation) to restrict the respiration of the beans. Respiration involves the oxidative breakdown of complex substrate molecules, normally present in plant cells, such as starch, sugars and organic acids to simpler molecules, in the course of which energy, carbon dioxide and water are given out. Atmospheres low in $\mathrm{O}_{2}$ (1-5\%) and high in $\mathrm{CO}_{2}(5-10 \%)$ have been used to extend the shelf-life of freshcut fruits and vegetables by reducing respiration, product transpiration and ethylene production, as $\mathrm{O}_{2}$ is involved in the conversion of 1-amino- cyclopranel-carboxylic acid to ethylene (Yang \& Hoffman, 1984). In general, an inverse relationship has been shown between respiration rates of fruits and vegetables and their postharvest shelf-life. Reduced $\mathrm{O}_{2}$ and high $\mathrm{CO}_{2}$ levels have also been proved to effectively control enzymatic browning, firmness and decay of freshcut fruits and vegetables. Besides, the proliferation of aerobic spoilage microorganisms can be substantially delayed with reduced $\mathrm{O}_{2}$ levels (Alejandra Rojas-Grau et al., 2009).

After packing, the vegetables were stored in ambient temperature. Temperature and humidity were recorded and close observations were made to record the physico-chemical parameters like moisture content, rotting/decay, acidity, vitamin $C$ and $\beta$-carotene of the beans.

Package perforation (\%): The perforations on the packets were made by using a puncher machine. The number of perforations on each packet was determined using the following calculation-

Area of each packet $=28 \mathrm{~cm} \times 26 \mathrm{~cm}=728 \mathrm{sq} \mathrm{cm}$

Diameter of each hole (dia. of puncher rod) $=0.4 \mathrm{~cm}$ 
From these data, number of perforations were calculated to be 29, 58 and 87 for $0.5,1.0$ and $1.5 \%$ perforation, respectively.

Shelf life (day): Shelf life of the beans was determined by observing and judging the quality parameters like rotting, shriveling, incidence of disease, etc. with respect to storage days. It was detected when most of the beans of a treatment were still marketable.

Decay/Rotting (\%): It is the percentage of the damaged beans. It was also determined by the quality parameters of the beans like rotting, shriveling, incidence of disease, etc.

Physico-chemical analysis: Acidity, vitamin C, $\beta$-carotene and moisture content were determined for the fresh beans and at $5^{\text {th }}$ to $8^{\text {th }}$ days of storage. Acidity was determined by titrating against standard $\mathrm{NaOH}$ solution, vitamin $\mathrm{C}$ (ascorbic acid) by 2,6-Dichlorophenol-Indophenol Visual Titration Method, $\beta$-carotene by AOAC (Association of Official Analytical Chemists) Method and moisture content by Oven Drying method. These methods were conducted according to Ranganna (1986).

Sensory evaluation: Sensory analysis uses human panelists and their senses of sight, flavour, taste, touch and bearing to measure the sensory characteristics and acceptability of food products, as well as many other materials (Watts et al., 1989). Stored beans were examined by a panel of judges comprising of scientific staff for their quality parameters like physical appearance, texture/shrinkage, rotting/decay and overall acceptance. Hedonic scale was used to mark the different parameters. In this scale 'like extremely' is given the highest score of 9 and 'dislike extremely' is given the lowest score of 1 . Others are given intermediate scores. The data were analyzed for ANOVA in completely randomized design (CRD) under computerized statistical methods of M-stat and least significant difference (LSD) was used to compare the means.

\section{Treatments}

$\mathrm{T}_{1}=$ Packet with zero perforation

$\mathrm{T}_{2}=$ Packet with $0.5 \%$ perforation

$\mathrm{T}_{3}=$ Packet with $1.0 \%$ perforation

$\mathrm{T}_{4}=$ Packet with $1.5 \%$ perforation

$\mathrm{T}_{5}=$ Control (without packet)

$\mathrm{C}_{0}=$ Without chlorine water treatment

$\mathrm{C}_{1}=$ With chlorine water treatment

\section{Results and Discussion}

Data on physico-chemical parameters (moisture content, total acid, vitamin C and $\beta$-carotene) and rotting/decay of beans were analyzed at 5th, 6th 7th and 8th day 
of storage at ambient temperature. Temperature was recorded during the experiment as $20-25^{\circ} \mathrm{C}$ (max.) and $14-16^{\circ} \mathrm{C}(\mathrm{mn}$.). Again, humidity was recorded as $65 \%-85 \%$ (at 9:00 am) and $50 \%-70 \%$ (at 4:30 pm). Since the effect of packaging technique and the combined effect of chlorination and packaging technique were significant in all cases, only the combined effects are described for interpretation as shown in the Table 1 to 3 .

Table 1 shows that beans packed in zero perforated packets $\left(\mathrm{C}_{1} \mathrm{~T}_{1}\right.$ treatment) conserved maximum moisture content (88.33\%) followed by CoT $_{1}$ after 8 days of storage at ambient temperature as shown in the Table 1 . The storage of the beans in the polypropylene packets conserved the moisture hence prevented shrinkage and reduced the weight loss. Beans kept in bulk without packaging lost moisture drastically and shriveled rapidly. On the other hand, beans in the perforated packets lost moisture with respect to perforated openings but slower than bulk and open storage.

Table 1. Combined effect of chlorine water treatment and packaging techniques on moisture content and decay/rotting of country beans during storage.

\begin{tabular}{|c|c|c|c|c|c|}
\hline \multirow{2}{*}{ Treatments } & \multicolumn{5}{|c|}{ Storage periods, days } \\
\hline & Od & $5 \mathrm{~d}$ & $6 \mathrm{~d}$ & $7 d$ & $8 d$ \\
\hline \multicolumn{6}{|c|}{ Moisture content, \% } \\
\hline $\mathrm{C}_{0} \mathrm{~T}_{1}$ & \multirow{10}{*}{89.15} & $\begin{array}{l}88.29 a \\
(69.97)\end{array}$ & $\begin{array}{l}\text { 88.03ab } \\
(69.73)\end{array}$ & $\begin{array}{l}87.19 b \\
(69.00)\end{array}$ & $\begin{array}{l}87.71 b \\
(69.45)\end{array}$ \\
\hline $\mathrm{C}_{0} \mathrm{~T}_{2}$ & & $\begin{array}{l}\text { 87.85abc } \\
(69.58)\end{array}$ & $\begin{array}{l}85.21 d \\
(67.36)\end{array}$ & $\begin{array}{l}86.64 c \\
(68.54)\end{array}$ & $\begin{array}{l}86.38 c \\
(68.32)\end{array}$ \\
\hline $\mathrm{C}_{0} \mathrm{~T}_{3}$ & & $\begin{array}{l}87.04 c \\
(68.88)\end{array}$ & $\begin{array}{l}84.72 a \\
(66.96)\end{array}$ & $\begin{array}{l}84.90 \mathrm{e} \\
(67.10)\end{array}$ & $\begin{array}{l}84.65 e \\
(66.91)\end{array}$ \\
\hline $\mathrm{C}_{0} \mathrm{~T}_{4}$ & & $\begin{array}{l}87.22 b c \\
(69.04)\end{array}$ & $\begin{array}{l}83.67 e \\
(66.14)\end{array}$ & $\begin{array}{l}84.21 f \\
(66.56)\end{array}$ & $\begin{array}{l}\text { 84.23ef } \\
(66.57)\end{array}$ \\
\hline $\mathrm{C}_{0} \mathrm{~T}_{5}$ & & $\begin{array}{l}79.61 \mathrm{e} \\
(63.13)\end{array}$ & - & - & - \\
\hline $\mathrm{C}_{1} \mathrm{~T}_{1}$ & & $\begin{array}{l}88.74 a \\
(70.37)\end{array}$ & $\begin{array}{l}88.44 a \\
(70.10)\end{array}$ & $\begin{array}{l}88.40 a \\
(70.06)\end{array}$ & $\begin{array}{l}88.33 a \\
(70.00)\end{array}$ \\
\hline $\mathrm{C}_{1} \mathrm{~T}_{2}$ & & $\begin{array}{l}\text { 88.20ab } \\
(69.88)\end{array}$ & $\begin{array}{l}87.93 b \\
(69.64)\end{array}$ & $\begin{array}{l}\text { 86.90bc } \\
(68.76)\end{array}$ & $\begin{array}{l}86.84 c \\
(68.70)\end{array}$ \\
\hline $\mathrm{C}_{1} \mathrm{~T}_{3}$ & & $\begin{array}{l}86.90 c \\
(68.75)\end{array}$ & $\begin{array}{l}86.54 c \\
(68.45)\end{array}$ & $\begin{array}{l}\text { 86.0ld } \\
(68.01)\end{array}$ & $\begin{array}{l}85.76 d \\
(67.80)\end{array}$ \\
\hline $\mathrm{C}_{1} \mathrm{~T}_{4}$ & & $\begin{array}{l}84.90 d \\
(67.14)\end{array}$ & $\begin{array}{l}84.82 d \\
(67.04)\end{array}$ & $\begin{array}{l}\text { 84.57ef } \\
(66.84)\end{array}$ & $\begin{array}{l}84.12 \mathrm{e} \\
(66.49)\end{array}$ \\
\hline $\mathrm{C}_{1} \mathrm{~T}_{5}$ & & $\begin{array}{l}79.42 \mathrm{e} \\
(63.11) \\
\end{array}$ & - & - & - \\
\hline CV (\%) & & 0.73 & 0.46 & 0.50 & 0.46 \\
\hline $\begin{array}{l}\text { Level of } \\
\text { significance }\end{array}$ & & $*$ & $*$ & $*$ & $*$ \\
\hline
\end{tabular}


Table 1. Cont'd.

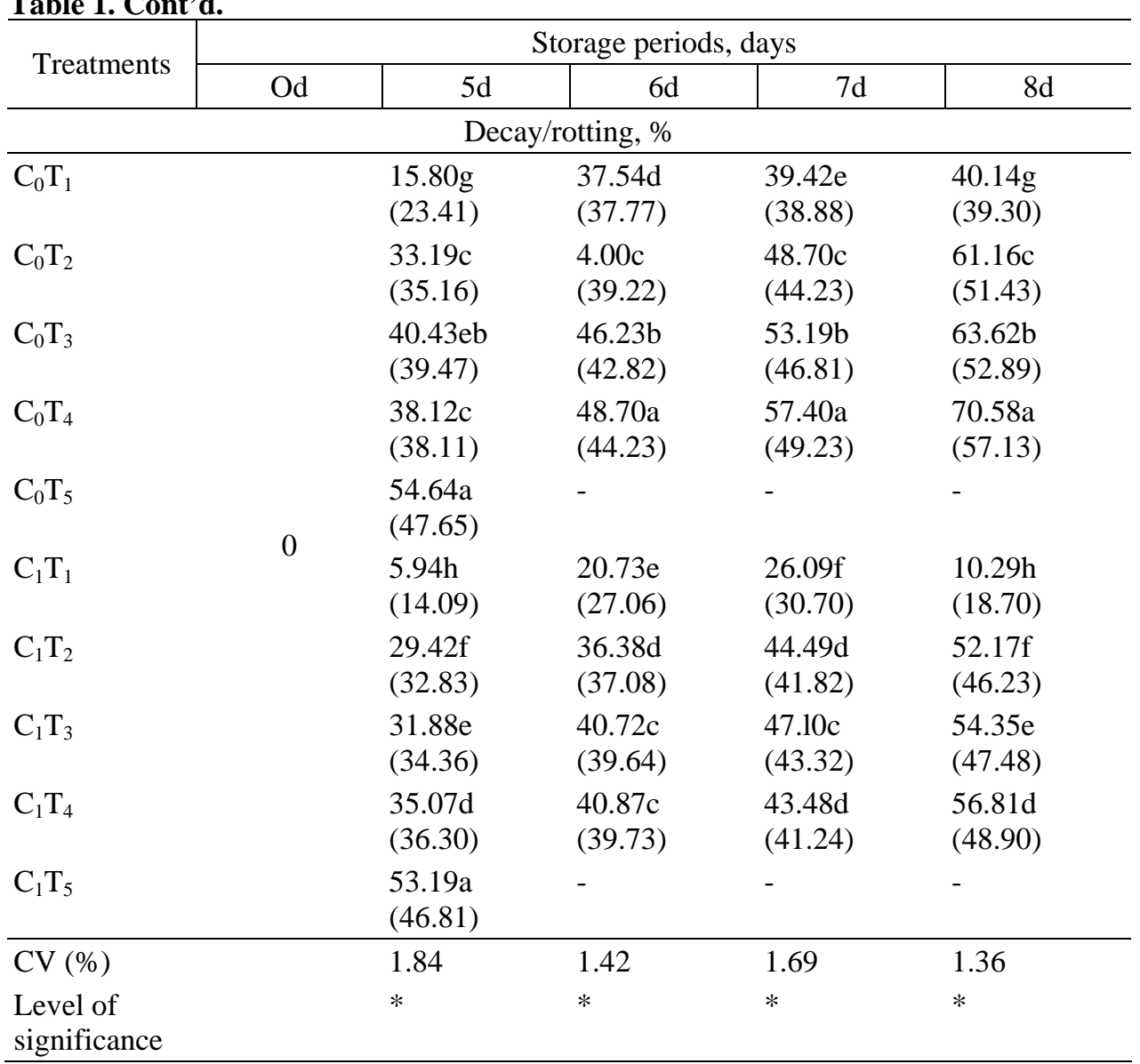

$\mathrm{d}=$ Days, $*=$ Significant at $5 \%$ level of probability. Figures in the parenthesis indicate the transform value of the original

At 8th day of storage period, beans treated with chlorine and packed in sealed polypropylene packets (combined effect of treatment $\mathrm{C}_{1} \mathrm{~T}_{1}$ ) had minimum rotting/decay (10.29\%) followed by the treatment $\mathrm{C}_{0} \mathrm{~T}_{1}(40.14 \%)$ as shown in the Table 1 . The rotting/decay of the beans was minimum as these were washed with chlorine water before packing that supports to those found by Giraldo (1977). The rotting/decay in the perforated packets was higher due to two reasons, firstly these packets did not conserve much moisture to prevent shriveling and secondly the little condensed moisture lead the shriveled beans to rot rapidly.

A substantial reduction was noted in ascorbic acid (vitamin C) and $\beta$ carotene (vitamin A) contents of the beans during storage. The reduction could be due to both oxidative and non-oxidative changes as described by Eskin (1979) and Land (1962). Such changes altered the colour of the beans and lowered the nutritive value of the beans. In case of combined effect, the maximum vitamin $\mathrm{C}$ 
and $\beta$-carotene retention was observed in treatment $\mathrm{C}_{1} \mathrm{~T}_{1}(15.65 \mathrm{mg} / 100 \mathrm{~g})$ and $\mathrm{C}_{1} \mathrm{~T}_{4}(11.76 \mu \mathrm{g} / \mathrm{g})$ followed by the treatment $\mathrm{C}_{0} \mathrm{~T}_{1}(10.62 \mathrm{mg} / 100 \mathrm{~g})$ and $\mathrm{C}_{0} \mathrm{~T}_{1}$ $(10.45 \mu \mathrm{g} / \mathrm{g})$, respectively, at 8th day of storage period (Table 2). Again maximum acidity retention was observed in $\mathrm{C}_{0} \mathrm{~T}_{1}(0.29 \%)$ followed by $\mathrm{C}_{0} \mathrm{~T}_{2}$ $(0.28 \%)$ at 8 th day of storage (Table 2$)$. These chemical and nutritional compositions and changing behaviours of the stored country beans support to those found by Salunkhe (1991).

Table 2. Combined effect of chlorine water treatment and packaging techniques on chemical and nutritional parameters of country beans during storage.

\begin{tabular}{|c|c|c|c|c|c|}
\hline \multirow{2}{*}{ Treatments } & \multicolumn{5}{|c|}{ Storage periods, days } \\
\hline & Od & $5 \mathrm{~d}$ & $6 \mathrm{~d}$ & $7 d$ & $8 \mathrm{~d}$ \\
\hline \multicolumn{6}{|c|}{ Vitamin C, mg/l00g } \\
\hline $\mathrm{C}_{0} \mathrm{~T}_{1}$ & \multirow{10}{*}{24.13} & $14.92 \mathrm{~d}$ & $15.26 \mathrm{~b}$ & $11.89 \mathrm{~b}$ & $10.62 b$ \\
\hline $\mathrm{C}_{0} \mathrm{~T}_{2}$ & & $17.23 b$ & $10.55 f$ & $11.72 b$ & $9.27 d$ \\
\hline $\mathrm{C}_{0} \mathrm{~T}_{3}$ & & $13.96 \mathrm{e}$ & $15.47 \mathrm{~b}$ & $10.30 \mathrm{c}$ & $8.56 \mathrm{e}$ \\
\hline $\mathrm{C}_{0} \mathrm{~T}_{4}$ & & $16.45 c$ & $13.92 \mathrm{c}$ & $11.84 \mathrm{~b}$ & $8.05 f$ \\
\hline $\mathrm{C}_{0} \mathrm{~T}_{5}$ & & $11.11 \mathrm{i}$ & - & - & - \\
\hline $\mathrm{C}_{1} \mathrm{~T}_{1}$ & & $20.47 \mathrm{a}$ & $19.94 a$ & $17.69 \mathrm{a}$ & $15.65 a$ \\
\hline $\mathrm{C}_{1} \mathrm{~T}_{2}$ & & 12.9lfg & $11.91 \mathrm{e}$ & $10.07 \mathrm{c}$ & $7.95 f$ \\
\hline $\mathrm{C}_{1} \mathrm{~T}_{3}$ & & 13.4lef & $13.37 \mathrm{c}$ & $12.13 b$ & $10.07 \mathrm{c}$ \\
\hline $\mathrm{C}_{1} \mathrm{~T}_{4}$ & & 12.53gh & $12.54 d$ & $10.49 c$ & $10.08 c$ \\
\hline $\mathrm{C}_{1} \mathrm{~T}_{5}$ & & $12.04 \mathrm{~h}$ & - & - & - \\
\hline CV (\%) & & 2.39 & 3.23 & 2.60 & 2.35 \\
\hline $\begin{array}{l}\text { Level of } \\
\text { significance }\end{array}$ & & $*$ & $*$ & * & * \\
\hline \multicolumn{6}{|c|}{$\beta$ - carotene, $\mu \mathrm{g} / \mathrm{g}$} \\
\hline$\overline{\mathrm{C}_{0} \mathrm{~T}_{1}}$ & \multirow{10}{*}{22.26} & $12.28 \mathrm{bc}$ & $10.5 \mathrm{lbc}$ & $10.52 b$ & $10.45 b$ \\
\hline $\mathrm{C}_{0} \mathrm{~T}_{2}$ & & 11.8lbc & $8.72 \mathrm{~d}$ & $8.26 \mathrm{e}$ & 7.61d \\
\hline $\mathrm{C}_{0} \mathrm{~T}_{3}$ & & $11.28 \mathrm{c}$ & 8.14de & $7.87 f$ & $7.31 \mathrm{~d}$ \\
\hline $\mathrm{C}_{0} \mathrm{~T}_{4}$ & & $9.45 d$ & $7.48 \mathrm{e}$ & $6.79 \mathrm{~g}$ & $5.87 f$ \\
\hline $\mathrm{C}_{0} \mathrm{~T}_{5}$ & & $9.35 d$ & - & - & - \\
\hline $\mathrm{C}_{1} \mathrm{~T}_{1}$ & & $15.76 a$ & $11.16 \mathrm{~b}$ & $8.75 \mathrm{~d}$ & $6.58 \mathrm{e}$ \\
\hline $\mathrm{C}_{1} \mathrm{~T}_{2}$ & & $12.93 \mathrm{~b}$ & $10.33 c$ & $9.04 c$ & 8.34c \\
\hline $\mathrm{C}_{1} \mathrm{~T}_{3}$ & & $12.43 \mathrm{bc}$ & $12.29 \mathrm{a}$ & $8.26 \mathrm{e}$ & $6.73 e$ \\
\hline $\mathrm{C}_{1} \mathrm{~T}_{4}$ & & $12.84 \mathrm{~b}$ & $12.62 \mathrm{a}$ & 12.15a & $11.76 \mathrm{a}$ \\
\hline $\mathrm{C}_{1} \mathrm{~T}_{5}$ & & $11.24 \mathrm{c}$ & - & - & - \\
\hline CV (\%) & & 5.32 & 5.01 & 2.05 & 2.92 \\
\hline $\begin{array}{l}\text { Level of } \\
\text { significance }\end{array}$ & & $*$ & * & $*$ & $*$ \\
\hline
\end{tabular}


Table 2. Cont'd.

\begin{tabular}{l|lll|l}
\hline \multirow{2}{*}{ Treatments } & \multicolumn{5}{c}{ Storage periods, days } \\
\cline { 2 - 6 } & Od & \multicolumn{5}{c}{$5 \mathrm{~d}$} & $6 \mathrm{~d}$ & $7 \mathrm{~d}$ & $8 \mathrm{~d}$ \\
\hline $\mathrm{C}_{0} \mathrm{~T}_{1}$ & $0.30 \mathrm{a}$ & $0.30 \mathrm{a}$ & $0.30 \mathrm{c}$ & $0.29 \mathrm{a}$ \\
$\mathrm{C}_{0} \mathrm{~T}_{2}$ & $0.27 \mathrm{c}$ & $0.17 \mathrm{~h}$ & $0.30 \mathrm{~b}$ & $0.28 \mathrm{c}$ \\
$\mathrm{C}_{0} \mathrm{~T}_{3}$ & $0.23 \mathrm{e}$ & $0.26 \mathrm{~b}$ & $0.25 \mathrm{~d}$ & $0.24 \mathrm{f}$ \\
$\mathrm{C}_{0} \mathrm{~T}_{4}$ & $0.21 \mathrm{f}$ & $0.28 \mathrm{c}$ & $0.19 \mathrm{f}$ & $0.22 \mathrm{~h}$ \\
$\mathrm{C}_{0} \mathrm{~T}_{5}$ & $0.17 \mathrm{~g}$ & - & - & - \\
$\mathrm{C}_{1} \mathrm{~T}_{1}$ & $0.23 \mathrm{e}$ & $0.23 \mathrm{f}$ & $0.19 \mathrm{f}$ & $0.24 \mathrm{e}$ \\
$\mathrm{C}_{1} \mathrm{~T}_{2}$ & $0.28 \mathrm{e}$ & $0.29 \mathrm{~b}$ & $0.17 \mathrm{~g}$ & $0.28 \mathrm{~b}$ \\
$\mathrm{C}_{1} \mathrm{~T}_{3}$ & $0.23 \mathrm{e}$ & $0.22 \mathrm{~g}$ & $0.36 \mathrm{a}$ & $0.23 \mathrm{~g}$ \\
$\mathrm{C}_{1} \mathrm{~T}_{4}$ & $0.25 \mathrm{~d}$ & $0.25 \mathrm{e}$ & $0.25 \mathrm{e}$ & $0.27 \mathrm{~d}$ \\
$\mathrm{C}_{1} \mathrm{~T}_{5}$ & $0.50 \mathrm{~h}$ & - & - & - \\
\hline $\mathrm{CV}$ (\%) & 5.32 & 5.01 & 2.05 & 2.92 \\
Level of & $*$ & $*$ & $*$ & $*$ \\
significance & & & & \\
\hline
\end{tabular}

$\mathrm{T}_{1}=$ Packet with zero perforation,

$\mathrm{C}_{0}=$ Without chlorine water treatment

$\mathrm{T}_{2}=$ Packet with $0.5 \%$ perforation,

$\mathrm{C}_{1}=$ With chlorine water treatment,

$\mathrm{T}_{3}=$ Packet with $1.0 \%$ perforation,

$\mathrm{d}=$ Days,

$\mathrm{T}_{4}=$ Packet with $1.5 \%$ perforation,

$*=$ Significant at $5 \%$ level of probability

$\mathrm{T}_{5}$ Control (without packet),

The sensory evaluation of the stored bean was conducted by a panel of 5 judges at $5^{\text {th }}$ and $8^{\text {th }}$ day of storage of the bean. The comments of the evaluation on physical appearance, texture, shriveling, rotting/decay and overall acceptance for combined effect are presented in Table 3. In case of combined effect, the highest score for acceptability was for the treatment $C_{1} T_{1}$ (7.83) followed by $C_{1} T_{2}$ (7.33) for $5^{\text {th }}$ day of storage and $C_{1} T_{1}(7.50)$ followed by $C_{0} T_{1}(6.83)$ for $8^{\text {th }}$ day of storage, respectively. Prevention of shrinkage by moisture conservation and reduction of rotting/decay through combined effect of chlorine pretreatment and packaging technique leads the beans to the highest acceptability even after 8 days of storage at ambient temperature. 
Table 3. Sensory evaluation of stored country beans in case of combined effect of chlorine water treatment and packaging techniques.

\begin{tabular}{|c|c|c|c|c|c|c|c|c|}
\hline \multirow{3}{*}{ Treatments } & \multicolumn{8}{|c|}{ Mean scores on sensory attributes } \\
\hline & \multicolumn{4}{|c|}{ After 5 days } & \multicolumn{4}{|c|}{ After 8 days } \\
\hline & $\begin{array}{c}\text { Physical } \\
\text { appea- } \\
\text { rance }\end{array}$ & $\begin{array}{c}\text { Texture/ } \\
\text { Shrinkage }\end{array}$ & $\begin{array}{c}\text { Totting/ } \\
\text { Decay }\end{array}$ & $\begin{array}{c}\text { Overall } \\
\text { accepta- } \\
\text { biligy }\end{array}$ & $\begin{array}{l}\text { Physical } \\
\text { appea- } \\
\text { rance }\end{array}$ & $\begin{array}{c}\text { Texture/ } \\
\text { Shrinkage }\end{array}$ & $\begin{array}{l}\text { Totting/ } \\
\text { Decay }\end{array}$ & $\begin{array}{c}\text { Overall } \\
\text { accepta- } \\
\text { biligy }\end{array}$ \\
\hline $\mathrm{C}_{0} \mathrm{~T}_{1}$ & $7.67 \mathrm{a}$ & $8.17 \mathrm{a}$ & $7.17 \mathrm{a}$ & $7.17 \mathrm{a}$ & $7.50 \mathrm{a}$ & $7.50 \mathrm{a}$ & 7.00a & $6.83 a$ \\
\hline $\mathrm{C}_{0} \mathrm{~T}_{2}$ & $5.50 \mathrm{bc}$ & $7.33 b$ & $5.83 b$ & 6.33a & $5.67 \mathrm{~b}$ & $5.33 b$ & $5.17 \mathrm{~b}$ & $5.33 b$ \\
\hline $\mathrm{C}_{0} \mathrm{~T}_{3}$ & $6.00 \mathrm{~b}$ & $7.33 b$ & $5.83 b$ & $5.67 \mathrm{~b}$ & $5.00 \mathrm{~b}$ & $4.83 b$ & $4.67 \mathrm{bc}$ & $4.50 \mathrm{c}$ \\
\hline $\mathrm{C}_{0} \mathrm{~T}_{4}$ & $6.17 b$ & $7.50 \mathrm{a}$ & $6.50 \mathrm{a}$ & $6.50 \mathrm{a}$ & $4.67 \mathrm{bc}$ & $4.17 \mathrm{bc}$ & $4.67 \mathrm{bc}$ & $4.83 \mathrm{bc}$ \\
\hline $\mathrm{C}_{0} \mathrm{~T}_{5}$ & $2.00 \mathrm{c}$ & $1.83 \mathrm{c}$ & $1.83 \mathrm{c}$ & $2.17 \mathrm{c}$ & $1.00 \mathrm{c}$ & $1.00 \mathrm{c}$ & $1.00 \mathrm{c}$ & $1.00 \mathrm{~d}$ \\
\hline $\mathrm{C}_{1} \mathrm{~T}_{1}$ & $8.00 \mathrm{a}$ & 8.33a & $7.50 \mathrm{a}$ & $7.83 a$ & 8.00a & 7.83a & 7.33a & $7.50 \mathrm{a}$ \\
\hline $\mathrm{C}_{1} \mathrm{~T}_{2}$ & $6.50 \mathrm{a}$ & $7.67 \mathrm{a}$ & $6.33 a$ & 7.33a & $6.67 \mathrm{a}$ & $5.67 \mathrm{~b}$ & $6.00 \mathrm{a}$ & $5.50 \mathrm{~b}$ \\
\hline $\mathrm{C}_{1} \mathrm{~T}_{3}$ & $6.17 b$ & $7.33 \mathrm{~b}$ & $6.00 \mathrm{~b}$ & $6.50 \mathrm{a}$ & $5.53 b$ & $5.17 \mathrm{~b}$ & $5.33 b$ & $5.50 \mathrm{~b}$ \\
\hline $\mathrm{C}_{1} \mathrm{~T}_{4}$ & $6.67 b$ & $7.67 \mathrm{a}$ & 7.33a & 7.17a & $6.00 \mathrm{a}$ & $5.17 \mathrm{~b}$ & $5.17 \mathrm{~b}$ & $5.33 b$ \\
\hline $\mathrm{C}_{1} \mathrm{~T}_{5}$ & $1.67 \mathrm{c}$ & $2.00 \mathrm{c}$ & $1.83 \mathrm{c}$ & $1.83 \mathrm{c}$ & $1.00 \mathrm{c}$ & $1.00 \mathrm{c}$ & $1.00 \mathrm{c}$ & $1.00 \mathrm{~d}$ \\
\hline $\mathrm{CV}$ & 13.90 & 8.45 & 15.49 & 14.34 & 12.07 & 15.22 & 13.02 & 12.79 \\
\hline $\begin{array}{l}\text { Lavel of } \\
\text { significance }\end{array}$ & ns & $*$ & ns & ns & ns & ns & ns & ns \\
\hline \multicolumn{4}{|c|}{$\mathrm{T}_{1}=$ Packet with zero perforation, } & \multicolumn{3}{|c|}{$1=$ Dislike extremely } & & \\
\hline \multicolumn{4}{|c|}{$\mathrm{T}_{2}=$ Packet with $0.5 \%$ perforation, } & \multicolumn{3}{|c|}{2 = Dislike very much } & & \\
\hline \multicolumn{4}{|c|}{$\mathrm{T}_{3}=$ Packet with $1.0 \%$ perforation, } & \multicolumn{3}{|c|}{3 = Dislike moderately } & & \\
\hline \multicolumn{4}{|c|}{$\mathrm{T}_{4}=$ Packet with $1.5 \%$ perforation, } & \multicolumn{3}{|c|}{$4=$ Dislike slightly } & & \\
\hline \multicolumn{4}{|c|}{$\mathrm{T}_{5}=$ Control (without packet) } & \multicolumn{3}{|c|}{$5=$ Neither like nor dislike } & & \\
\hline \multicolumn{4}{|c|}{$\mathrm{C}_{0}$ Without chlorine water treatment, } & \multicolumn{3}{|c|}{6 = Like slightly } & & \\
\hline \multicolumn{4}{|c|}{$\mathrm{C}_{1}=$ With chlorine water treatment, } & \multicolumn{3}{|c|}{7 = Like moderately } & & \\
\hline \multicolumn{4}{|c|}{ ns $=$ Not significant at $5 \%$ level of probability } & \multicolumn{3}{|c|}{$8=$ Like very much } & & \\
\hline \multicolumn{4}{|c|}{$*=$ Significant at $5 \%$ level of probability } & \multicolumn{3}{|c|}{$9=$ Like extremely } & & \\
\hline
\end{tabular}

\section{Conclusion}

It could be concluded from the above analysis of findings that beans pre-treated with chlorine water and then packaging in sealed polypropylene is the best for quality and shelf life for 8 days of storage at ambient temperature.

\section{References}

Amiruzzaman M. 2000. Postharvest Technology/Management (vegetables). A consultancy report. AVRDC-USAID Bangladesh Project. pp-193.

Alejandra Rojas-Grau” M., Gemma Oms-Oliu, Robert Soliva-Fortuny and Olga Marti’nBelloso 2009. The use of packaging techniques to maintain freshness in fresh-cut 
fruits and vegetables: a review. International Journal of Food Science and Technology 44: 875-889

AOAC. 1984. Official Methods of Analysis. $14^{\text {th }}$ edn. Association of Official Analytical Chemists, Arlington.

DAE. 2006. Agricultural Information Service, Khamarbari, Dhaka. Pp 5-6

Eskin, N.A.M. 1979. Plant pigments, flavours and textures. The Chemistry and Biochemistry of Selected Compounds. Academic Press, London.

Giraldo L.F., R.A. Forero, C.R. Salazar and R. Torres. 1977. The Effect of Packaging and Potassium Permanganate on the Storage of Tomatoes under Room Conditions. Ravista Inst. Collanbiano Agropecuario 12 (4): 393-405. (Hort, Abstr. 49:4289)

Land, D.G. 1962. Stability of plant pigments. Advanced Food Research 2: 50-56.

Ranganna S. 1986. Hand Book of Analysis and Quality Control for Fruits and Vegetables Products. Tata McGraw-Hill Publishing Company Limited.

Salunkhe D.K., H.R. Bolin and N.R. Reddy. 1991. Storage, processing and nutritional quality of fruits and vegetables (2” edition), CRC Press, Boston, USA.

Saikia P., C.R. Sarkar and I. Borua. 1999. Chemical composition, antinutritional factors and effect of cooking on nutritional quality of rice bean [Vigna umbellate (Thunb; Ohwi and Ohashi)]. Food Chemistry 67: 347-352.

Watts, B. M., G. L. Ylimaki, L. E. Jeffery and L. G. Elias. 1989. Sensory Methods for Food Evaluation. The International Development Research Center, Ottawa, 160p.

Yang, S.F. and N.E. Hoffman. 1984. Ethylene biosynthesis and its regulation in higher plants. Annual Review of Plant Physiology 35: 155-189. 